Int. J. Electrochem. Sci., 11 (2016) $4712-4723$

International Journal of

ELECTROCHEMICAL

SCIENCE

www.electrochemsci.org

\title{
Synthesis of Copper Nanoparticles with Various Sizes and Shapes: Application as a Superior Non-Enzymatic Sensor and Antibacterial Agent
}

\author{
EmanAlzahrani ${ }^{1, *}$, Rasha A. Ahmed ${ }^{1,2, *}$ \\ ${ }^{1}$ Chemistry Department, Faculty of Science, Taif University, 888-Taif, Kingdom of Saudi Arabia. \\ ${ }^{2}$ Forensic Chemistry Laboratories, Medico Legal Department, Ministry of Justice, Cairo, Egypt. \\ *E-mail: em-s-z@hotmail.com, rashaauf@yahoo.com
}

doi: $10.20964 / 2016.06 .83$

Received: 7 February 2016 / Accepted: 5 April 2016 / Published: 4 May 2016

Copper nanoparticles (CuNPs) play an important role in optics, electronics, and antimicrobial fields. In this work we reported, synthesized CuNPs with various sizes and shapes by a facile chemical reduction of copper nitrate $\mathrm{Cu}\left(\mathrm{NO}_{3}\right)_{2}$ solution using isopropyl alcohol (IPA) as a reducing agent and cetyltrimethyl ammonium bromide $(\mathrm{CTAB})$ as a capping agent. The relationships between the $\mathrm{Cu}\left(\mathrm{NO}_{3}\right)_{2}$ and $\mathrm{CTAB}$ concentration ratios and the size of the CuNPs were elucidated by optical measurements. It was found that at a high CTAB concentration, hexagonal CuNPs were formed. In contrast, at a high concentration of copper nitrate, spherical CuNPs were formed in aggregations. From the TEM analysis, it was found that the CuNPs exhibit three different sizes (16, 23, and $37 \mathrm{~nm}$ ), which displayed characteristic adsorption bands at 551-572 $\mathrm{nm}$. The electrocatalytic activities of the CuNPs with different sizes and shapes towards $\mathrm{H}_{2} \mathrm{O}_{2}$ were systematically explored, and it was found that the electrocatalytic activity was strongly dependent on the microstructure of CuNPs, through changing the oxidation current values of the CuNPs. The cyclic voltammetry results showed that ratio 1:2 CTAB: $\mathrm{Cu}\left(\mathrm{NO}_{3}\right)_{2}$ exhibited good electrocatalytic activity than other ratios. Furthermore, the proposed sensor demonstrated significant antibacterial activities against gram-negative (E. coli) more than grampositive ( $S$. aureus) bacteria. In summary, this work demonstrates a facile, economic and fast method for the fabrication of copper nanoparticles with high catalytic activity using CTAB/IPA, which have potential as a non-enzymatic sensor for $\mathrm{H}_{2} \mathrm{O}_{2}$ detection and could be used in biomedical applications.

Keywords: Copper nanoparticle; CTAB; Modified electrode; Electrochemistry; $\mathrm{H}_{2} \mathrm{O}_{2}$ detection; Antimicrobial.

\section{$\underline{\text { FULL TEXT }}$}


(C) 2016 The Authors. Published by ESG (www.electrochemsci.org). This article is an open access article distributed under the terms and conditions of the Creative Commons Attribution license (http://creativecommons.org/licenses/by/4.0/). 